\title{
MARITIME JURISDICTION OVER VESSEL-SOURCE POLLUTION IN THE EXCLUSIVE ECONOMIC ZONE: THE CHINESE EXPERIENCE
}

\author{
Zou Keyuan*
}

The issue of marine environmental protection in the exclusive economic zone (EEZ) has only recently emerged after the establishment of the EEZ regime under the 1982 United Nations Convention on the Law of the Sea (the LOS Convention). Since about $90 \%$ of the marine living resources is to be found in the EEZ and most of the human maritime activities also take place near the shore, environmental protection has become a critical aspect of the comprehensive management of the EEZ. According to the LOS Convention, a coastal state has the right to take necessary measures to prevent and control vessel-source pollution in its EEZ. ${ }^{1}$ This raises maritime jurisdictional issues in the context of the following questions: to what extent can a coastal state exercise its legitimate right in laying down laws and regulations to protect the natural resources within its EEZ, and in taking measures to combat vessel-source marine pollution including the punishment of the offending vessel?

China is a big coastal state with a coastline of more than 18,000 kilometres along its mainland and thousands of islands scattered in the China seas. At the time of its ratification of the LOS Convention in May 1996, China made a statement declaring its intention to establish an EEZ. On 26 June 1998 China promulgated the Law on the EEZ and the Continental Shelf, ${ }^{2}$ although the exact outermost limits of China's EEZ is still unknown. The present paper attempts to examine and assess the jurisdictional rights of a coastal state in terms of control of vessel-source pollution in its EEZ and, in particular, the Chinese practice in regard to the above two questions.

\footnotetext{
* Faculty of Law, Peking University, Beijing; East Asian Institute, National University of Singapore. The author is grateful to Prof. JOHN WONG for his helpful editorial suggestions on a previous version of this paper.

${ }^{1}$ Arts.56, 211.

${ }^{2}$ Adopted by the Third Session of the Ninth National People's Congress held in June 1998. People's Daily [in Chinese], 27 June 1998. English translation in Law of the Sea Bulletin No.38 at 28-31; somewhat different translation by the present author in The MIMA [Malaysian Institute of Maritime Affairs] Bulletin, Vol.7 (1999) No.1 at 27-29.
}

Asian Yearbook of International Law, Volume 7 (Ko Swan Sik et al., eds.

- Kluwer Law International; printed in the Netherlands), pp. 243-260 


\section{VESSEL-SOURCE MARINE POLLUTION AND INTERNATIONAL LEGISLATION}

Marine pollution is defined in the LOS Convention as:

"the introduction by man, directly or indirectly, of substances or energy into the marine environment, including estuaries, which results or is likely to result in such deleterious effects as harm to living resources and marine life, hazards to human health, hindrance to marine activities, including fishing and other legitimate uses of the sea, impairment of quality for use of sea water and reduction of amenities."3

In terms of its sources, marine pollution is generally divided into six categories according to its source: land-based sources, sea-bed activities subject to national jurisdiction, pollution from the International Sea-Bed Area; dumping of waste at sea; pollution from or through the atmosphere; and pollution from vessels. ${ }^{4}$ Vessel-source pollution consists mainly of pollution from ship cargoes, ${ }^{5}$ and is either operational or accidental. It is estimated that the marine environment is polluted by about 5 million tons of oil, of which $47 \%$ is from ships. Operational pollution is a function of the manner in which ships operate. Oil tankers, for example, traditionally wash their oil tanks and dispose of oil residues at sea, causing significant pollution. ${ }^{6}$ More serious is the deliberate discharge from vessels at sea. According to BIRNIE, 3.5 tons of oil per annum are deliberately discharged or result from accidental spills globally - half from marine-based sources, mainly shipping. ${ }^{7}$

China borders on four seas, i.e., the Bohai Sea, the Yellow Sea, the East China Sea and the South China Sea. The state of the marine environment is generally good, but according to recent trends the quality of the sea water will get worse if no more effective measures are taken immediately. While the main pollution of the China seas, or about $80 \%$ of the total, is land-based pollution, vessel-source pollution cannot be ignored, since all the seas involved are categorized as semi-enclosed under the definition of the LOS Convention, with a heavy concentration of shipping routes. ${ }^{8}$ One of the major pollutants in the

\footnotetext{
${ }^{3}$ LOS Convention Art.1(4). Text of the Convention in, inter alia: The Law of the Sea: Official Text of the United Nations Convention on the Law of the Sea with Annexes and Index (United Nations, 1983). The Convention entered into force on 16 November 1994.

${ }^{4}$ LOS Convention Arts.207-212.

${ }^{5}$ DOUGLAS BRUBAKER, Marine pollution and international law: principles and practice (1993) 34.

${ }^{6}$ PATRICIA W. BiRNie \& AlAN E. Boyle, International law and the environment (1992) 263.

${ }^{7}$ PATRICIA BIRNIE, "Pollution and fisheries in the North Sea", in GeIR Ulfstein et al.(eds.), The regulations of fisheries: legal, economic and social aspects [proceedings of a European workshop] ( 1986) 200.

${ }^{8}$ EDGaR GOLD and Douglas JohnSTON, "Pollution control in the semi-enclosed seas of East Asia", in CHOON-HO PARK AND JAE KYU PARK (eds.), The law of the sea: problems from the East Asian perspective (1987) 96-97.
} 
China seas is oil, originating mainly from maritime transportation. According to incomplete statistics, from 1979 to 1984 there were 18 oil tanker incidents each spilling more than 100 tons of oil in China's sea areas, with a total spill of 21,000 tons. $^{9}$ The normal discharge of waste oil from vessels into the sea around China is 46,000 tons annually, accounting for $52 \%$ of the total quantity of oil discharged into the sea. ${ }^{10}$ It is predicted that in the next one or two decades, oil pollution will increase with the development of the off-shore petroleum industry as well as maritime transportation, and that there will be a similarly increasing potential threat from vessel-source oil pollution. ${ }^{11}$ In the year 2000 , more than 360,000 tons of oil pollutants will go into the sea, double the quantity in the $1980 \mathrm{~s},{ }^{12}$ causing severe damage to the marine environment. It was reported in May 2000 that the quality of China's marine environment had been deteriotrating continuously despite the implementation of the Law on Marine Environmental Protection for nearly 20 years. ${ }^{13}$ For these reasons, it is important for China to exercise jurisdiction over vessel-source pollution in its EEZ.

The efforts to lay down international legislation on the control of oil pollution from vessels began in 1926 when the United States sponsored a diplomatic conference on the issue. The conference produced a draft convention which, however, was not adopted. Related efforts made by the League of Nations in 1934 were also to no avail. The first treaty on the control of oil pollution from ships was the International Convention on Prevention of Oil Pollution at Sea which was adopted in London on 12 May $1954 .{ }^{14}$ The Convention affirmed the exclusive jurisdiction of the flag state over vessel-source oil pollution. The basis for this rule was provided by the generally accepted idea at that time that a ship was deemed to constitute part of the territory of the flag state, and the cardinal principle of freedom of navigation. However, the rule has proved to be inadequate in protecting the marine environment of the EEZ, for the following reasons:

(1) The EEZ is a sea area sui generis, where the coastal state enjoys sovereign rights and jurisdiction over the protection and preservation of the marine environment. Excessive emphasis on the exclusive jurisdiction of the flag state would be detrimental to the interests and rights of the coastal state.

\footnotetext{
${ }^{9}$ Marine technological policy [China Blue Paper on Science and Technology, No.9, National Commission of Science and Technology, in Chinese] (1993) 254.

${ }^{10}$ WANG WeIJIE and Wu ChangJiang, "The harm from marine oil pollution for the fishery and its countermeasures", Ocean and Coastal Zone Development [in Chinese] Vol.11(1994) No.1:33.

${ }^{11}$ Series on the Chinese Natural Resources: Ocean [Compiling Committee of the Series on the Chinese Natural Resources (CCSCNR), in Chinese](1995) 129.

${ }^{12}$ Strengthening the comprehensive management and improving the marine ecological environment [Report of investigation of the management of China's marine ecological environment, Department of Management and Monitoring, State Oceanic Administration, in Chinese] (November 1995) 19. (on file with the author)

${ }^{13}$ People's Daily 19 May 2000; see infra n.42.

14327 UNTS 3.
} 
(2) If a vessel causes pollution in the EEZ of another state and the flag state fails to exercise its jurisdiction by ensuring adequate laws and regulations and their enforcement with respect to the vessel, the consequence would be that the offending vessel would escape its responsibility and liability.

(3) It is doubtful whether the flag state is able to exercise effective jurisdiction over vessels navigating far from the flag state.

(4) The rule does not guarantee the effective exercise of jurisdiction by a 'flag of convenience' state over vessels flying its flag, while enabling a vessel to avoid the effective jurisdiction of any state by flying a 'flag of convenience'. ${ }^{15}$

Partly due to the above reasons, the 1958 Convention on the High Seas set certain limitations to the jurisdiction of the flag state in its Articles 6, 24 and 25 , with some exceptions, such as the right of the coastal state to lay down anti-pollution laws and regulations. ${ }^{16}$

Because of the Torrey Canyon incident in $1967^{17}$, the world community began to consider the question whether a coastal state which finds itself threatened with oil pollution damage of such magnitude should be entitled to take control of the situation, even against the will of other interested states or persons ${ }^{18}$ As a result, two international conventions were adopted in Brussels in November 1969, among which was the International Convention Relating to the Intervention on the High Seas in Case of Oil Pollution Casualties (commonly known as the Public Law Convention). It acknowledged the jurisdiction of the coastal State over marine pollution on the high seas. Its Article 1 grants the coastal State the right after a marine casualty to "take such measures on the high seas as may be necessary to prevent, mitigate or eliminate" grave danger to their coastlines or related interests from threats of or actual oil pollution. ${ }^{19}$ Accordingly, the Convention was called 'epoch-making'. ${ }^{20}$ The jurisdiction of the coastal state, however, was limited to cases of marine oil pollution, while other hazardous substances such as radioactive substances were not included in the Convention. The later International Convention for the Prevention of Pollution from Ships (MARPOL 73/78) ${ }^{21}$ somewhat remedied the deficiency and covered not only oil pollution but also pollution by other hazardous substances.

${ }^{15}$ Cf. Zou KeYUAN, "Jurisdiction of the coastal state over vessel-source pollution in its exclusive economic zone", Journal of the Southern Central Institute of Political Science and Law [in Chinese] Vol.11 (1987) No.4:61.

${ }^{16} 450$ UNTS 11. The People's Republic of China is not a party to this Convention. The English language version of the Convention uses the words "pollution of the seas", whereas the Chinese version refers to "pollution of the high seas". Both are authentic texts. The difference could cause different interpretations that could affect the exercise of jurisdiction.

${ }^{17}$ Dictionary of international law [Japanese Society of International Law, Chinese edition] (1985) 267-268.

${ }^{18}$ DAVID W. ABECASSIS, The law and practice relating to oil pollution from ships (1978) at 84.

${ }^{19} 970$ UNTS 211; 9 ILM (1970) 25. The Convention entered into force on 6 May 1975.

${ }^{20}$ HIROBE WANO, "Marine pollution and international conventions", Foreign Legal Science [in Chinese] 1980 No.5:25.

${ }^{21} 12$ ILM (1973) 1319 and 17 ILM (1978) 546. On 1 July 1983 China notified the International Maritime Organisation that China acceded to MARPOL 73/78, without its Annexes III, IV and 
As we can see from the foregoing, the jurisdiction of the coastal state over vessel-source pollution was not recognized under the traditional international law of the sea and was only achieved through constant efforts and demands of the coastal states. The establishment of such jurisdiction was no doubt revolutionary and a reflection of the modern requirements of science and technology. ${ }^{22}$ Nevertheless, the jurisdiction of the flag state remained superior to that of the coastal state, and the contradiction between the conflicting interests and contrary views of the maritime powers and coastal states could not be solved until the Third United Nations Conference on the Law of the Sea (UNCLOS III).

\section{UNCLOS III AND THE LOS CONVENTION}

UNCLOS III ushered in a new era with regard to the enhancement of the jurisdiction of the coastal state over vessel-source pollution, particularly in the EEZ, which was a new concept formulated and adopted by the Conference. As early as 1972, Kenya submitted a proposal on the EEZ to the UN Seabed Committee, suggesting that the coastal state should have exclusive jurisdiction in its EEZ for the purpose of preventing and controlling marine pollution. ${ }^{23} \mathrm{On}$ 31 July 1974 ten countries led by India and the Philippines submitted a joint proposal to UNCLOS III, concerning regional measures for marine environmental protection including a provision relating to the EEZ, to the effect that the coastal state should have jurisdiction to make and enforce laws and regulations as well as to take administrative and other measures regarding activities of all natural or legal persons, vessels, installations and other entities, in order to protect the marine environment of the EEZ. ${ }^{24}$ Finally, the following two main theses may be derived from the various proposals on the EEZ in relation to vessel-source pollution that were put forward by the developing countries at UNCLOS III: (1) the coastal state is entitled to make laws and regulations on vessel-source pollution apart from the international rules and standards; and (2) the coastal state enjoys jurisdiction over the polluting vessel.

On the other hand, the maritime powers insisted on the traditional rule of the exclusive jurisdiction of the flag state, in accordance with their own interests and in order to maintain the freedom of navigation. They feared that if the coastal state were given jurisdiction over a polluting vessel in its EEZ, it would have a pretext to interfere in the freedom of navigation. As a consequence,

\footnotetext{
V. Accession to Annex III took place on 13 Sep.1994, to Annex V on 21 Nov.1988. The 1978 Protocol came into force on 2 October 1983. See 6 AsYIL (1996) 241.

${ }^{22}$ Compare CHEN ZHIFANG, speech on marine environmental protection in the Third Committee of the Seabed Committee, 2 Aug.1972, in Collected materials on the law of the sea, edited by Peking University, Department of Law, Division of Int'l Law [in Chinese] (1974) 39-40.

${ }^{23}$ A/AC.138/SC.II/L.10, or see ZHAO LIHAI, New developments of the law of the sea [in Chinese](1984) at 167.

${ }^{24}$ UN Doc.A/CONF.62/C.3/L.6 (1974).
} 
"such regulation, at best, would impose an unwarranted impediment on ocean traffic by reason of the complexity of a system of differing national regulations; and, at worst, it would be employed as a subterfuge aimed directly at restricting traffic, perhaps discriminatorily, for economic or political reasons". ${ }^{25}$ The Soviet Union took a reserved stand towards the idea of jurisdiction exercised by the coastal state, and stated that unilateral measures would only result in conflict. It proposed to apply international norms and standards instead of laws and regulations of the coastal state to vessel-source pollution. ${ }^{26}$ At the Sixth Session of UNCLOS III, for example, the Soviet Union suggested that the jurisdiction of the coastal state would be limited to vessel-source pollution in its EEZ resulting from discharges, excluding other kinds of pollution by foreign vessels. ${ }^{27}$ In a word, the attitude of the maritime powers towards the jurisdiction of the coastal State was negative. They preferred uniform international rules and standards while emphasizing the jurisdiction of the flag State.

It should be pointed out that some of the developed countries were on the side of the developing countries during UNCLOS III. A typical example was Canada, which was one of the ten states endorsing the joint proposal mentioned earlier. It had advanced domestic legislation on jurisdiction over vessel-source marine pollution. As early as 1970, Canada had promulgated the Prevention of Arctic Pollution Act, ${ }^{28}$ which claimed Canadian jurisdiction over marine pollution cases up to 100 nautical miles from the Canadian coast. Any vessel which did not comply with the Act would be prohibited to enter the Arctic waters and be subject to inspection and detention. Against the opposition from the United States, Canada stated that it "cannot accept the right of innocent passage if that right is defined as precluding the right of a coastal state to control pollution in such cases. The law is underdeveloped on this question but if that is the case, we propose to develop it".$^{29}$ Through the efforts of Canada and other countries the 1970 Canadian Act became the basis for the formulation of Article 234 of the LOS Convention. ${ }^{30}$

\footnotetext{
${ }^{25}$ J. HARGROVE, "Environment and the Third Conference on the Law of the Sea" in BURNS H. WESTON et al (eds.), International law and world order: A problem-oriented coursebook (1980) at 902 .

${ }^{26}$ See ZHAO, supra $\mathrm{n} .23$ at $169-170$.

${ }^{27}$ Ibid. at 172.

${ }^{28}$ Act of 17 June 1970, 9 ILM (1970) 543.

${ }^{29}$ T.L. GILL, "Marine pollution and international law", in RAM P.ANAND (ed.), Law of the sea: Caracas and beyond (1980) at 324.

${ }^{30}$ Art.234 provides that "coastal States have the right to adopt and enforce non-discriminatory laws and regulations for the prevention, reduction and control of marine pollution from vessels in ice-covered areas within the limits of the exclusive economic zone, where particularly severe climatic conditions and the presence of ice covering such areas for most of the year create obstructions or exceptional hazards to navigation, and the pollution of the marine environment could cause major harm to or irreversible disturbance of the ecological balance. Such laws and regulations shall have due regard to navigation and the protection and preservation of the marine environment based on the best available scientific evidence".
} 
China regarded herself as a developing country and naturally stood on the side of these countries. First, China explained her position on marine environmental pollution at the Conference to the effect that "each State has the right to formulate its environmental policy and take all necessary measures to protect its marine environment and prevent pollution in the sea areas under its national jurisdiction. In so doing, the coastal States should of course have regard for the interests of all and those of its neighbouring countries". When the marine environment was damaged by outside pollution, the coastal state should have the right to ask compensation from the country of the polluter. ${ }^{31}$ China emphasized the jurisdiction of the coastal state and regarded the measures taken by the coastal State to protect its marine environment and natural resources from foreign pollution as the natural extension of the right of preservation of the coastal State according to international law. China supported the practice of expanding the maritime jurisdiction of the coastal state in its environmental area, such as the Canadian expansion of its maritime jurisdiction by the 1970 Arctic Waters Pollution Act. ${ }^{32}$

Second, China was against substituting international standards for coastal state jurisdiction and thus weakening the role of that state in the prevention and control of marine pollution. At the same time China deemed it necessary to establish a legal regime on the global or regional level to protect and preserve the marine environment. ${ }^{33}$ On the question of the prevention of vessel-source pollution, the Chinese delegation to UNCLOS III defended the right of coastal states to establish and enforce their national laws, regulations, and standards to prevent such pollution in its EEZ and above its continental shelf in accordance with actual circumstances. ${ }^{34}$ The Chinese delegation also criticized the words "enforce through international rules and standards made by the competent international organization or general diplomatic conferences" contained in Article 21(4) of the Revised Composite Negotiation Text (RCNT), pointing out that it would weaken the jurisdiction of the coastal state over the prevention of pollution within its sea areas. A single international rule or standard would be impractical and difficult to meet the requirements for marine environmental protection of different countries. If the coastal states were forced to implement uniform international rules and standards, it would protect vessels, but bring harm to the marine environment, or protect one part of the marine environment, but damage other parts of it. It would thus be neither favourable for the maintenance of the maritime interests of the coastal state, nor beneficial for the effec-

\footnotetext{
${ }^{31}$ CHEN, supra n.22 at 40-41.

${ }^{32}$ UN Doc. Ä/AC 138/SC III/SR 25 (1972).

${ }^{33}$ LUO YURU, speech on the marine environment in the Third Committee of UNCLOS III, in Collected documents of the Chinese delegation to relevant UN Conferences [in Chinese](1974) at 299-300.

${ }^{34}$ Speech of the Chinese delegate on the prevention of vessel-source pollution at the 32nd Meeting of the Third Committee, 15 Sep.1976, UNCLOS III, 5th Session, 6 Collected Documents of the Chinese delegation to relevant UN Conferences, July-December 1976 [in Chinese](1976) at 186.
} 
tive protection of the marine environment. ${ }^{35}$ After various discussions and revisions, China's views may finally be deemed reflected in Article 211(5) of the LOS Convention as the RCNT wording was revised and became "all generally accepted international rules and standards".

According to the LOS Convention, the coastal state has sovereign rights in its EEZ for the purpose of exploring and exploiting, conserving and managing all kinds of natural resources therein, and jurisdiction with regard to the protection and preservation of the marine environment. ${ }^{36}$ This provision provides a legal basis for the coastal state to exercise its power in its EEZ with respect to the control of vessel-source pollution.

In regard to vessel-source pollution in particular, the LOS Convention (Art.211 para.5) provides that a coastal state may, for the purpose of enforcement, in respect of its EEZ adopt laws and regulations for the prevention, reduction and control of pollution from vessels, though under the condition of "conforming to and giving effect to generally accepted international rules and standards established through the competent international organization or general diplomatic conference." If (Art.211 para.6) the international rules and standards "are inadequate to meet special circumstances" while a coastal state has reasonable grounds for believing that some part of its EEZ requires special mandatory measures for the prevention of pollution from vessels because of "recognized technical reasons in relation to its oceanographical and ecological conditions, as well as its utilization or the protection of its resources and the particular character of its traffic", the coastal state may, subject to consultation with other states and permission of competent international organizations, adopt laws and regulations, for the implementation of "such international rules and standards or navigational practices as are made applicable, through the organization, for special areas" ${ }^{37}$ This is a further development of previous international regulations on marine pollution. The 1954 Convention on the Prevention of Pollution from Oil did not contain a provision on designation of special protected areas, while MARPOL $73 / 78$ does contain provisions on special areas, but confined itself to oil discharge and specifically listed sea areas, such as the Mediterranean, the Baltic, etc. ${ }^{38}$

With regard to the exercise of jurisdiction by a coastal state over vesselsource pollution the LOS Convention contain the following relevant rules:

1. States shall take all measures consistent with the Convention that are necessary to prevent, reduce and control pollution of the marine environment from any source (Art.194 para.1). States shall take all measures necessary to ensure that activities under their jurisdiction or control are so conducted as not to cause damage by pollution to other states and their environment, and that pollution arising from incidents or activities under their jurisdiction or control does

\footnotetext{
${ }^{35}$ Ibid. p. 187.

${ }^{36}$ LOS Convention Art.56 para.1.

${ }^{37}$ LOS Convention Art.211 paras 5 and 6.

${ }^{38}$ MARPOL 73/78 Annex I Art. 10.
} 
not spread beyond the areas where they exercise sovereign rights in accordance with the Convention (Art.194 para.2). Article 194 (3) provides that "the measures taken ... shall deal with all sources of pollution of the marine environment. These measures shall include, inter alia, those designed to minimise to the fullest possible extent: .... (b) pollution from vessels, in particular measures for preventing accidents and dealing with emergencies, ensuring the safety of operations at sea, preventing intentional and unintentional discharges, and regulating the design, construction, equipment, operation and manning of vessels". Article 220 further provides that "[w]hen a vessel is voluntarily within a port or at an off-shore terminal of a State, that State may ... institute proceedings in respect of any violation of its laws and regulations adopted ... for the prevention, reduction and control of pollution from vessels when the violation has occurred within the territorial sea or the exclusive economic zone of that State".

2. Where there are clear grounds for believing that a vessel navigating in the eez or the territorial sea of a state has, in the eez, committed a violation of applicable international rules and standards or laws and regulations of that state conforming and giving effect to such rules and standards, that state may require the vessel to give information regarding its identity and port of registry, its last and its next port of call and other relevant information required to establish whether a violation has occurred (art.220 para.3).

3. Where there are clear grounds for believing that a vessel navigating in the EEZ or the territorial sea of a state has, in the EEZ, committed a violation resulting in a substantial discharge causing or threatening significant pollution of the marine environment, that State may undertake physical inspection of the vessel if the vessel has refused to give information or the information supplied is manifestly at variance with the evident factual situation (Art.220 para.5).

4. Where there is clear objective evidence that a vessel navigating in the EEZ or the territorial sea of a State has, in the EEZ, committed a violation resulting in a discharge causing major damage or threat of major damage to the coastline or related interests of the coastal State, or to any resources of its territorial sea or the EEZ, that State may, institute proceedings, including detention of the vessel (Art.220 para.6).

5. Article 230(1) provides that "monetary penalties only may be imposed with respect to violations of national laws and regulations or applicable international rules and standards .... committed by foreign vessels beyond the territorial sea".

These rules are clearer and more detailed in comparison with similar provisions contained in previous relevant conventions. They basically reflect an advanced approach to the matter and generally satisfy the demands from the coastal states with respect to jurisdiction over vessel-source pollution. ${ }^{39}$

${ }^{39}$ See SHAO JIN, "Legal nature of the exclusive economic zone", Study on Maritime Issues [in Chinese] 1983 No.2:32. 
As we know, however, the LOS Convention is the result of compromise after many years of multilateral consultations and negotiations. Particularly, the provisions on the jurisdiction of the flag state or the coastal state over vesselsource pollution reflect a compromise between the developing countries and the maritime powers. Therefore, the jurisdiction of the coastal state is made the subject of a number of restrictive stipulations. On the one hand, the coastal state has a right to make laws and regulations for its EEZ, but, on the other hand, such laws and regulations must conform to the generally accepted international rules and standards. ${ }^{40}$ That is equivalent to prohibiting the coastal state to adopt stricter laws and regulations than the international rules and standards. Moreover, the adoption of enforcing measures, visit, inspection, notification and institution of proceedings including the detention of the vessel may only be conducted if major damage or threat of such damage to the coastal State has really occurred and only if the coastal State has 'clear grounds' and 'evidence so warrants'. These limitations are reflected in Article 220 paragraphs 2, 5 and 6 of the Convention described above. Besides, the penalty to be imposed by the coastal state upon the polluting vessel is confined to 'monetary penalties' (Art.230). This means that the coastal state is not entitled to impose the sterner punishment which is available in case of pollution incidents which occur in its territorial sea. In addition, Section 7 of Part XII of the Convention (Articles 223-233) provides detailed safeguard measures which practically restrict the exercise of the coastal state's jurisdiction in case of vessel-source pollution. For example, Article 228 prescribes, albeit subject to exceptions, the suspension of "proceedings to impose penalties in respect of any violation of applicable laws and regulations or international rules and standards relating to the prevention, reduction and control of pollution from vessels committed by a foreign vessel beyond the territorial sea of the State instituting proceedings" upon the taking of proceedings in respect of corresponding charges by the flag State within six months of the institution of the earlier proceedings by the coastal state. This provision in fact puts the jurisdiction of the flag State above that of the coastal State. ${ }^{41}$ In addition, the LOS Convention grants jurisdiction to the port state by way of counterbalance vis-a-vis the coastal state. Consequently, we can conclude from the foregoing that the jurisdiction of the coastal state over vesselsource pollution in its EEZ is limited.

Notwithstanding these limitations, the provisions of the LOS Convention on the jurisdiction of the coastal state in its EEZ are most meaningful as a further development of the achievements of previous conventions in favour of coastal state jurisdiction. It indicates an epochal trend and is testimony of the significant contributions made on this issue by the developing countries.

\footnotetext{
${ }^{40}$ LOS Convention Art.211(5).

${ }^{41}$ As ATTARD noted, "[u]nder the 1982 Convention, a coastal State has little prescriptive competence over vessel-source pollution in the EEZ independent of, or in addition to, the measures originating from an international organisation or diplomatic conferences". DAVID JOSEPH ATTARD, The exclusive economic zone in international law (1987) at 98.
} 


\section{CHINESE LEGISLATION AND PRACTICE}

During UNCLOS III, the Chinese delegation stressed the necessity and importance of the jurisdiction of the coastal State over vessel-source pollution in its EEZ. In implementing the LOS Convention that acknowledged such jurisdiction China enacted the Marine Environment Protection Law (MEPL) in 1982 , effective 1 March $1983 .{ }^{42}$ It was the first basic law on marine environmental protection in China. Its Article 2 clearly stipulates: "This Law applies to the internal sea and territorial sea of the People's Republic of China and all other sea areas under the jurisdiction of the People's Republic of China”, while it enjoins all vessels to comply with it. It should be noted that at the time China had not yet established its EEZ, so that the words "other sea areas under the jurisdiction of the PRC" could only potentially refer to the EEZ. Before the actual establishment of the EEZ the words could apply only to the waters above the continental shelf. However, the article further provides in its paragraph 3 that "[t]his Law also applies to the discharge of harmful substances and the dumping of wastes done beyond the sea areas under the jurisdiction of the People's Republic of China but causing pollution damage to such areas". This means that, even if China could not exercise its jurisdiction over the vesselsource pollution in a potential, not yet existing, EEZ, it still could invoke the third paragraph of Article 2 of the Law to take necessary measures against a vessel that is causing damage to China on the high seas. The Law on the EEZ and the Continental Shelf of 26 June $1998^{43}$ affirmed China's jurisdiction over marine pollution in its EEZ. Article 10 of the Law provides that " $[t]$ he authorities in charge ... shall have the right to take necessary measures to prevent, reduce and control marine pollution, and to protect and preserve the marine environment in the exclusive economic zone and the continental shelf".

The MEPL contains several other pertinent provisions regarding the vesselsource pollution in the EEZ:

- No vessel shall discharge oils, oil mixtures, wastes and other harmful substances into the sea areas under China's jurisdiction in violation of the law (Art.26). In case a vessel is involved in a marine accident which has caused, or is likely to cause, serious pollution damage to the marine environment, the Harbcur Superintendency Administration has the power to take mandatory measures to avoid or minimise such pollution damage (Art.35).

- In the event of pollution caused by vessels that navigate, berth or operate in a sea area under Chinese jurisdiction, officers from the Harbour Super-

${ }^{42}$ Chinese text and English translation in Collection of the sea laws and regulations of the People's Republic of China [Office of Laws and Regulations, Department of Ocean Management and Monitoring, State Oceanic Administration, ed.] (1991) 69-93; English translation in The laws of the People's Republic of China 1979-1982 [Standing Committee of the National People's Congress, Legislative Affairs Commission, ed.] 296.

${ }^{43}$ See supra, n.2. 
intendency Administration or other officers under the latter's authority may board the vessel in question to examine and handle the case (Art.37).

- In case of a violation of the Law that has caused, or is likely to cause, pollution damage to the marine environment, the offender may be ordered to remedy the pollution damage within a definite time, and to pay a discharge fee, the cost for clean-up, and compensation for the losses sustained by the state. A fine may also be imposed on the offender (Art.41). In case of a violation of the law resulting in pollution damage to the marine environment and causing heavy losses to public or private property or deaths or injuries to persons, those who are directly responsible may be prosecuted for criminal responsibility (Art.44).

As we have seen the MEPL establishes Chinese jurisdiction over vesselsource pollution, generally in accordance with the relevant provisions of the LOS Convention. ${ }^{44}$ It reflects the preservation of the rights and interests of China as a coastal State, and affirms the obligations of China deriving from the LOS Convention. Besides, the MEPL can also be seen as aiming at harmony with the relevant provisions of MARPOL 73/78. ${ }^{45}$

The enforcement of the law in respect of prevention and control of vesselsource pollution in China principally rests with the Harbour Superintendency Administration, which is in charge of navigational matters. It was established in 1950 and has branches in major ports such as Shanghai, Tianjin, Qingdao, and Dalian. ${ }^{46} 47$

In order to implement the MEPL China promulgated the Regulations Concerning the Prevention of Pollution of Sea Areas by Vessels. ${ }^{48}$ The Regulations have elaborated the provisions of the MEPL, and apply to Chinese and foreign vessels within the sea areas and sea ports under China's jurisdiction, as well as to shipowners and other individuals (Art.2). The Regulations prescribe, inter alia, that in case of pollution accidents, vessels shall immediately takes steps to control and eliminate the pollution, and report to the nearest Harbour Superin-

\footnotetext{
${ }^{44}$ An opposite view holds that China's claim to jurisdiction over vessels outside its territorial sea contradicts the general principles of international law. See MITCHELL A. SILK, Marine environmental protection law: the dragon creeping in murky waters [Occasional Papers/Reprints Series in Contemporary Asian Studies, School of Law, University of Maryland] No.6 (1985) 17.

45 YAN JINSEN, "Guiding thoughts and principles of the Marine Environmental Protection Law", Study on Maritime Issues [in Chinese] 1983 No.1 at 20-21.

${ }^{46}$ For details, see ZOU KEYUAN, "The establishment of a marine legal system in China", 13 International Journal of Marine and Coastal Law (1998) 38.

${ }^{47}$ However, since 1983, vessels and aircraft of the China Marine Surveillance, under the direction of the State Oceanic Administration (SOA) have been dispatched to patrol the sea areas under Chinese jurisdiction for the purpose of pollution monitoring. On numbers of patrols and violations of the law, see Working summary of twelve years implementation of the Law on the Marine Environmental Protection [State Oceanic Administration (SOA), discussion paper, in Chinese], December 1995 at 2 (on file with the author).

${ }^{48}$ Regulations of 29 Dec.1983, Collection of the sea laws, supra $\mathrm{n} .42$ at 127.
} 
tendency Administration (Art.6). In case of severe environmental damage, the latter may take whatever compulsory steps are necessary to avoid or mitigate any pollution damage, including compulsory clean-up and compulsory towage (Art.7), oblige the polluting vessel to pay the cost of eliminating the pollution and to compensate for the losses suffered by the state (Art.39), and give warnings or impose a fine (Art.46). As to foreign vessels, the Regulations take account of the international relations of China by granting them treatment on the flexible basis of reciprocity. ${ }^{49}$

In addition to the above Regulations, the Ministry of Communications promulgated the Regulations Governing the Investigation and Settlement of Maritime Traffic Accidents in $1990 .^{50}$ Though the definition of the term "maritime traffic accidents" does not specifically refer to vessel-source pollution, it is assumed that the Regulations also cover vessel-source pollution, in light of the following wording of the definition of the term in Article 4: "(1) collision, striking between vessels or installations, swell damages; (2) striking a reef or running aground; (3) fire or explosion; (4) sinking; (5) damage or loss of machine parts or important instruments affecting the seaworthiness in the course of navigation; (6) other maritime accidents causing property damage or injury and loss of life".

China may exercise its jurisdiction over vessel-source pollution, including in the sea areas beyond its territorial sea through the aforementioned laws and regulations.$^{51}$ In the early 1980 s, the most serious vessel-source oil pollution accident since the foundation of the People's Republic of China occurred in a sea area beyond the Chinese territorial sea. The Nanyang, an oil tanker belonging to a Hong Kong-based ocean transport company but flying the Somalian flag, while navigating from Qingdao towards Zhanjiang with 16,488 crude oil, collided with a Dutch freighter (owned by another Hong Kong-based ocean transport company), as a result of which the Nanyang sank in the sea area near Haifeng County of Guangdong Province. A large quantity of oil spilled over, polluting a large surrounding area. In connection with the accident, a Chinese court began judicial proceedings under the 1974 Provisional Regulations on the Prevention of Pollution in the Offshore Areas of the People's Republic of China and the 1969 International Convention Relating to the Intervention on the High Seas in Case of Oil Pollution Casualties. The owner of the Dutch freighter initially raised objection to the jurisdiction of the Chinese court on the ground that the accident had occurred outside the Chinese territo-

${ }^{49}$ Article 53 provides that "all foreign vessels shall, besides observing these Regulations, be subject to the same treatment as those accorded to Chinese vessels by the foreign countries concerned". Collection of the sea laws etc., supra n.42 at 147.

${ }^{50}$ Collection of the sea laws etc., supra $\mathrm{n} .42$ at 268.

${ }^{51}$ In implementing the MEPL and regulations, the Harbour Superintendency Administration in the past years dealt with more than 6,800 incidents of vessel-source pollution, of which 1,300 were related to foreign vessels. Since 1986, 38,923 inspection teams have been sent on board vessels to check the international certificates of oil pollution prevention and oil records. See Working summary, supra n. 47 at 4. 
rial sea. The Chinese court dismissed the objection, holding that under the 1969 Convention, the coastal state was entitled to intervene in oil pollution accidents on the high seas, to take necessary measures to prevent potential damage to the marine environment caused by the accident, and to inspect, detain and institute proceedings against the vessel which has caused severe damage. The court finally decided that the damage inflicted upon the Chinese marine environment amounted to 7,923,216 Chinese yuan, of which the Dutch freighter had to bear $65 \%$ and the Nanyang side $35 \%$. In addition, the two parties were to bear the costs accruing from salvage and the settlement of maritime matters. ${ }^{52}$

The above case provides an example of the way in which China asserted its jurisdiction over its potential EEZ area even before the establishment of such a zone. However, the case left over a number of questions. First, there is the question of the legal basis for the decision. The report does not refer to the exact time of the incident. We assume that the 1982 MEPL and the 1983 Regulations on Vessel-Source Pollution had not yet come into being or entered into force, and that, consequently, the court could only rely upon the 1974 Provisional Regulations. The uncertainty is reinforced by the fact that the court invoked the 1969 Intervention Convention, to which China was not yet a party at the time. ${ }^{53}$ The reference to the Convention was, therefore, unjustified unless the relevant provisions of the Convention must be deemed to have become customary international law. In casu, however, the parties did not raise objections to the grounds taken for the court's decision. Finally, we do not know how the court has calculated the damage resulting from the incident. There should have been some evaluation procedure. It may be assumed that the evaluation procedure in Chinese judicial practice consists of the following elements:

(1) determination of the precise nature of the pollution in question, which is distinguished from other forms of pollution in order to establish its relative seriousness; and

(2) determining the appropriate courses of action for the purpose of minimizing the pollution damage or restoring the environment in its original state before the pollution..$^{54}$

In fact, the relevant courts seem to acknowledge that the evaluation of the consequences of environmental pollution in legal proceedings is an enormously lengthy process which require a great deal of human resources. ${ }^{55}$

\footnotetext{
52 "After the sinking of the Nanyang in the Shan Wei sea area ...", Democracy and Law [in Chinese] 1984 No.9: 23-24.

${ }^{53}$ China acceded to the Convention on 23 February 1990. See 6 AsYIL (1996) 238.

${ }^{54}$ WANG MAO SHEN et al., "The normal procedure of assessment of damage to the marine environment in Chinese judicial practice", in COLIN M. DE LA RUE (ed.), Liability for damage to the marine environment (1993) 30.

${ }^{55}$ WANG $e t$ al., ibid.at 30-31.
} 


\section{FUTURE PROSPECTS}

Changing situations and new developments require the introduction of new legal concepts into the existing legal framework of marine environmental protection and, consequently, the addition to or amendment of existing rules. The Ocean Agenda 21 of China ${ }^{56}$ has laid down a number of aims in developing and improving the existing legal framework. They include the following three objectives: (1) "establish and improve the legal and standard systems for the marine environmental protection", (2) "establish and improve the marine environmental protection law enforcement system, and the supporting and supervising mechanism"; and (3) "develop the mechanism for the communication among marine administration units, marine environmental protection institutions and the public". ${ }^{57}$

It was reported that the National Environmental Protection Administration regarded the revision of the law as the main item on its 1995 agenda ${ }^{58}$ In that year China decided to revise and amend the MEPL in order to cope with the changed situation and new developments. The amendment process is still going on and various institutions and entities at the central and local level will be involved in consultations. ${ }^{59}$ It is expected that the prevention and control of vessel-source pollution will be further strengthened. On the other hand, international legislation on the matter has become tighter. The annexes to MARPOL 73/78 include amendments with stricter norms and standards for the prevention and control of vessel-source pollution..$^{60}$ As a party to MARPOL 73/78, China has to consider accepting the new requirements. Finally, the International Maritime Organisation (IMO) has recently introduced the Vessel Traffic Services (VTS), ${ }^{61}$ which is optional for the coastal State to adopt. With it the IMO has lent its support to a mandatory ship reporting system that has been developed in state practice. It is worthwhile for China to consider these new developments which could serve the prevention and control of vessel-source pollution in its EEZ.

In the field of enforcement, recent years have witnessed the equipment of oil-water separators aboard ships of all types in accordance with relevant regulations. On the other hand, equipment for oil-polluted water treatment, includ-

\footnotetext{
${ }^{56}$ China Ocean Agenda 21 [State Oceanic Administration, ed.](1996).

${ }^{57}$ Ibid. at 94.

${ }^{58}$ China Environmental Yearbook 1996 [in Chinese](1996) at 169.

${ }^{59}$ People's Daily [in Chinese], 15 May 1998.

60 See "Major international instruments relating to the marine environment", on: http://www.un.org/Depts/los/los_me2.htm\#offshoreregion (access date: 7 May 1998).

${ }^{61}$ A VTS is any service implemented by a competent authority, designed to improve safety and efficiency of traffic and the protection of the environment. It may range from the provision of simple information messages to extensive management of traffic within a port or waterway. See Guidelines for Vessel Traffic Services (IMO, 1985), cited in ERIK FRANCKX, "Coastal state jurisdiction with respect to marine pollution - some recent developments and future challenges", 10 International Journal of Marine and Coastal Law (1995) at 262 n.58.
} 
ing emergency treatment, has been installed at all sea ports in China. This equipment can help dispose of 3.7 million tons of oil-polluted water from vessels and recover 42,000 tons of waste oil annually. In addition, a Crash Programme to Combat Ships' Oil Pollution has been formulated. ${ }^{62}$ Despite these efforts, however, there are still gaps in enforcement. For example, in view of the development of offshore oil exploitation and oil transportation it is most desirable to set up an oil-spill emergent response system. Most of the developed coastal States already have such systems, but are not yet available in China.. According to the Ninth Five-Year Plan and Long-Term Plan towards 2010 for China's Marine Environmental Protection, a model project of the oil-spill response system in the Bohai Sea is planned as a matter of urgency.$^{63}$ Further, the recently released White Paper on Marine Development has determined the following as among the measures for the protection of China's marine environment: the enhancement of investigation, monitoring and control of marine pollution by improving the monitoring network, strengthening of surveillance by satellites, ships and offshore monitoring stations, and perfecting the law enforcement system. ${ }^{64}$ The establishment of an EEZ has greatly expanded the maritime jurisdictional area and the corresponding task of enforcement. Further integration of the enforcement system would certainly increase its effectiveness.

An effective exercise of jurisdiction over vessel-source pollution in the EEZ also depends upon regional co-operation in East Asia. At present, there are two regional programmes on marine environmental protection in the region. One is the East Asian Seas Programme, the other the Northwest Pacific Regional Seas Programme. China has participated in the activities of these two programmes since their inception. The former is jointly sponsored by the IMO, the United Nations Development Programme, the Global Environmental Facility and the World Bank. Its overall objective is to support the efforts of the participating countries in the prevention and management of marine pollution at both the national and sub-regional levels on a long-term and self-reliant basis. ${ }^{65}$ One of the objectives of the latter programme, which is sponsored by the United Nations Environment Programme (UNEP), is to develop and adopt a harmonious approach towards the integrated management of the coastal and marine environment and its resources, in a manner which combines protection, restoration, conservation and sustainable use. ${ }^{66}$ The two programmes will no doubt facilitate the Chinese efforts to prevent and control pollution in its EEZ. The fact that the China seas are all semi-enclosed and bordered on by more

\footnotetext{
62 "Marine Development White Paper", China Daily, 29 May 1998:4.

${ }^{63}$ State Oceanic Administration, The ninth five-year plan and long-term plan towards 2010 for China's marine environmental protection [in Chinese], January 1995, at 30-32 (on file with the author).

${ }^{64}$ China Daily, 29 May 1998.

${ }^{65}$ "Fighting pollution in the East Asian Seas", IMO News 4/97, on: http://www.imo.org/imo/ news/3\&497/drchua2.htm (access date: 27 February 1998).

${ }^{66}$ UNEP, Action Plan for the protection, management and development of the marine and coastal environment of the Northwest Pacific region, NOWPAP Publication No.1,1997 at 5.
} 
than two countries make international cooperation even more pressing. The Chinese EEZ is part of these seas and borders to those of other countries. The LOS Convention requires the coastal states bordering on semi-enclosed seas "to co-ordinate the implementation of their rights and duties with respect to the protection and preservation of the marine environment" ${ }^{67}$ It is, therefore, suggested that some kind of joint arrangements be made in exercising coastal jurisdiction over vessel-source pollution in the EEZs in East Asia.

During UNCLOS III, China was an enthusiastic supporter of the idea of establishing jurisdiction of the coastal State over vessel-source pollution in the EEZ without condition. However, after two decades and a rapid growth of its economy, China has developed one of the largest merchant fleets in the world. By the end of 1997, the number of merchant ships under Chinese flag had increased to 32,000 with a total dead-weight tonnage of close to 50 million, of which more than 23 million consisted of ships involved in foreign trade transportation. ${ }^{68}$ In view of such change in its situation, China might like to reconsider its previous position of emphasizing jurisdiction of the coastal state in contradistinction to that of the flag state. China is now confronted with the delicate problem of balancing the two contrary views in light of its interests.

The LOS Convention has created three types of jurisdiction over vesselsource pollution in the EEZ. Consequently, potential conflicts of jurisdiction may be expected to arise between the coastal state and the flag state or the port state. ${ }^{69}$ The possibility of such conflicts raises the need for a procedure of dispute settlement such as provided by the LOS Convention. It is to be assumed that China has accepted arbitration in accordance with the relevant provisions of the LOS Convention. ${ }^{70}$ Disputes concerning navigation and marine environmental protection in the EEZ are subject to compulsory settlement procedures. ${ }^{71}$ As to overlapping jurisdictions over vessel-source pollution in the EEZ

${ }^{67}$ LOS Convention, Art.123 item (b).

${ }^{68}$ China Daily, 29 May 1998.

${ }^{69}$ The complexity of this regime may imply the increased risk of disputes between the coastal state and other states about the respective competences in matters of marine pollution. See FRANCISCO ORREGO VICUÑA, The exclusive economic zone: regime and legal nature under international law (1989) at 88.

${ }^{70}$ Art.287 provides (para.1) that "[w]hen signing, ratifying or acceding to this Convention or at any time thereafter, a State shall be free to choose, by means of a written declaration, one or more of the following means for the settlement of disputes concerning the interpretation or application of this Convention:

(a) the International Tribunal for the Law of the Sea established in accordance with Annex VI;

(b) the International Court of Justice;

(c) an arbitral tribunal constituted in accordance with Annex VII;

(d) a special arbitral tribunal constituted in accordance with Annex VIII for one or more of the categories of disputes specified therein."

It further provides (para.3) that "a State Party, which is a party to a dispute not covered by a declaration in force, shall be deemed to have accepted arbitration in accordance with Annex VII".

${ }^{71}$ As BoYLE noted, "the inclusion of navigation and protection of the environment within compulsory jurisdiction was intended mainly to restrain coastal state claims to 'creeping jurisdiction' 
Article 292 of the LOS Convention is most relevant in regard to the prompt release of vessels and crews. ${ }^{72}$ In such circumstances China, as a coastal state exercising its jurisdiction, may be compulsorily sued before the International Tribunal for the Law of the Sea or an alternative arbitral tribunal. In view of this possibility, China may prefer to be more cautious and careful in exercising its jurisdiction over foreign vessels in its EEZ, since the LOS Convention rules are relatively favourable for the flag state.

over shipping, and it reinforces the balance established by Parts V and XII in favour of freedom of navigation. ALAN E. BOYLE, "UNCLOS, the marine environment and the settlement of disputes", in HENRIK RINGBOM (ed.), Competing norms in the law of marine environmental protection (1997) at 249.

${ }^{72}$ The article prescribes that "[w]here the authorities of a State Party have detained a vessel flying the flag of another State Party and it is alleged that the detaining State has not complied with the provisions of this Convention for the prompt release of the vessel or its crew upon the posting of a reasonable bond or other financial security, the question of release from detention may be submitted to any court or tribunal agreed upon by the parties or, failing such agreement within 10 days from the time of detention, to a court or tribunal accepted by the detaining State under article 287 or to the International Tribunal for the Law of the Sea, unless the parties otherwise agree." For reference, see RAINER LAGONI, "The prompt release of vessels and crews before the International Tribunal for the Law of the Sea: A preparatory report", 11 International Journal of Marine and Coastal Law (1996) at 147-164. 